\title{
Typology and Dynamics of Financial-Industrial Groups Operating in the Czech Republic and Slovakia ${ }^{*}$
}

\author{
Danes BRZICA \\ Slovak Academy of Sciences, Bratislava, Slovak Republic
}

\begin{abstract}
The contribution of this paper is threefold. Firstly, it develops a typology of corporate group development in terms of the pattern of corporate group formation in the Czech Republic and Slovakia. It identifies briefly three important types of corporate groups - industrial groups (type I groups), pyramid-like (type II) groups, and financial (type III or FIGs) groups. Using original typology for corporate groups, the paper examines development trajectory of some of the biggest FIGs and shows what effects their existence have in the two economies. Finally, some lessons resulting from this corporate group-related type of ownership concentration for other pre-transitive countries are mentioned.
\end{abstract}

Keywords: financial-industrial groups, The Czech Republic, Slovakia, restructuring, corporate governance

\section{Introduction}

Transformation towards market economy has been completed across Central and Eastern European countries (CEECs). Since its start in early 1990s, this process has represented numerous reform processes, radical shifts in institutional settings and many other aspects affecting business actors as well as citizens. Despite the specter of changes, the most visible aspect of reforms was privatization process. It is not our aim here to review all main features of the process but rather to look at how specific institutional setting, regulation, and policy steps affected the emergence and development of financial-industrial groups (type III groups or FIGs) in the Czech Republic (CR) and Slovak Republic (SR). To demonstrate magnitude of FIGs power, one good example is PPF group from the Czech Republic majority-owned by Kellner. Mr. Kellner's position was among the top 100 richest men of the world as of 2010. Other groups, although smaller, are also important players on the domestic and (Central) European markets.

The contribution of our paper is threefold. Firstly, it develops a typology of corporate group development in terms of the pattern of corporate group formation in the Czech Republic and Slovakia. Briefly, it identifies three important types of corporate groups in these countries: these being industrial groups, pyramid-like groups, and financial groups. Our research tries to show how group-related process of ownership concentration has developed

\footnotetext{
* Acknowledgment: This paper was published with the support of grant VEGA number 2/0080/12. The author would like to thank for the comments on an earlier versions of this article to participants at conferences in Stockholm, Sydney and Seoul. The author also wants to thank for useful comments to M. Rafferty from The University of Sydney Business School.

Danes BRZICA, Ing., Ph.D., Institute of Economic Research, Slovak Academy of Sciences.

Correspondence concerning this article should be addressed to Danes BRZICA, Institute of Economic Research, Slovak Academy of Sciences, Sancova 56, 81105 Bratislava, Slovak Republic. E-mail: danes.brzica@gmail.com.
} 
since the beginning of transition. In the early transition process, industrial groups emerged as significant ways of overcoming the weaknesses in financial markets and property rights confronting industrial firms, themselves facing significant restructuring pressures. Later groups (pyramid-like) emerged out of the process of collecting funds from the public, especially in Slovakia, on the promise of very high returns from stock trading and investment. However, these groups were quite unstable and unprofitable forms of investment and losses to small lenders/investors were common. Indeed, as with pyramid type schemes elsewhere, many pyramid-like groups were characterized by flagrant theft and corruption, and their activities quickly came to be considered to be risky or illegal. Not surprisingly then, their history was to paraphrase Hobbes, nasty brutish and short. This paper aims also to analyze emergence and developmental trajectories of FIGs in the two countries, and finally to formulate some general policy lessons from transformation process related to FISGs. The structure of the paper corresponds to the above three areas.

\section{Theoretical Issues Related to Groups and Basic Typology}

The theory of firm has a well-established literature covering several aspects of firm structure and performance. Some of the traditional works on firm structure and performance include Demsetz (1983), March and Simon (1958), and many others. However, some new areas of research have been introduced recently to the traditional areas. Among these are, e.g., issues of ownership concentration and corporate governance. Tirole (1991) represents one important work that explores the newer areas in the context of developments in CEECs. The standard textbook account of the firm tells us that increased size often brings greater efficiency, but that as a firm grows beyond a certain size it may in fact become absolutely less efficient. This size/performance paradigm has been a centerpiece of research on the firm for decades. One reason provided by the literature on optimal size/performance is that as a corporate group grows it eventually becomes more difficult to organize and manage. Thus, some diseconomies may begin to arise because of the firm exceeding optimal size. Problems with the firm size often relate to difficulties in coordination and control of group activities.

Most existing research on the development of the corporate sector in the Czech Republic and Slovakia has to date focused on the mechanisms and effects of voucher privatization. Some have taken this analysis further and attempted to estimate also the impact of investment funds on the process. Notable here is the work of Ellerman (1998), Mertlik (1997), and more broadly Simoneti, Estrin, and Boehm (1999), and Olsson (1999). In general, these studies tell a rather gloomy story about the impact of these methods of privatization and financial structure on market and corporate development. The privatization process helped to introduce companies and markets in a formal sense, but as such could not provide mechanisms to ensure that they operated in ways that anywhere near approached those of developed market economies. Privatization by vouchers generated an initially dispersed ownership structure, but was rapidly overwhelmed by developments that have led to highly concentrated ownership forms (e.g., Olsson and Brzica, 2001). In earlier research by the author, it was established if it was possible to identify the emergence of several different types of corporate group structures.

Research into ownership concentration has typically been made in terms of industry concentration ratios, average corporate size or other such indicators. These indicators provide a very good standardized snapshot of industry or firm structure and offer the possibility of using inter-industry or cross-country comparisons of various types. However, it is difficult to use such data for tracing the dynamics of industrial concentration in a country 
undergoing rapid change. In the case of the countries under study, where rapid changes in both the scale and nature of concentration has been a central feature, such static measures may not therefore be especially useful. In such cases, it may be better to use case studies instead. Another reason for adopting this research strategy is that data limitations are themselves quite constraining. We simply do not have enough data at either industry or individual company level due to privacy restrictions imposed on statistical agencies, except for the limited data disclosed through the stock market. This paper therefore employs selected sample analysis as a way of attempting to improve our understanding of corporate ownership structures in the Czech and Slovak Republics. Before moving to that analysis, the paper attempts to specify the structural features of type III firms in more detail.

Uncertainty is considered an important factor contributing to the emergence of business groups. Along with incomplete information and transaction costs, different degrees of uncertainty can lead to higher or lower degrees of group concentration. Dynamics and flexibility go hand in hand with pragmatism leading to what has been known as co-competition (competition through cooperation). It is therefore no surprise that the type III groups make no ideological, political or other selection in finding their strategic/tactical partners or in following their strategic goals. In such cases, this sort of opportunism is not to be taken as an absence of strategy. Instead, in a rapidly changing corporate and institutional environment, it may be a logical and profitable strategic orientation. To be successful in such activities, each group usually has to have its own legal, consulting, and brokering agency or at least have good access to some good independent ones. In addition, previously purely industrial groups have typically transformed into financial-industrial groups by acquiring important financial firms (e.g., Komarek's acquisition of Atlantik finanční trhy).

Theories of economic concentration are frequently misinterpreted. The evolution of groups in transition economies, often neglected in studies ${ }^{1}$ of transition reforms, can shed light on concentration patterns and determinants. We cannot overemphasize the importance of these groups for understanding the influence and patterns of foreign investment and their role in economic development. The ability to capture and control large equity stakes of whatever sort are surely results of tough inter- and intra-national competition. Group interdependence (Williamson, 1975) is the most serious of the alleged dangers of group formation. The process is not unlike that of a traditional oligopoly. Competition is restrained out of the mutually recognized dependence. This may take form of less aggressive competition in markets, where interfaces exist, or a reduction in potential competition in markets where entry might otherwise occur.

In order to make the analysis more understandable, the paper introduces a brief typology of corporate groups, which have appeared in the two economies since 1990s. Table 1 provides a simplified typology that characterizes three different sets of corporate groups. The taxonomy used to differentiate the three main group types identified is based on multiple criteria and not purely on strict quantitative parameters. Importantly, criteria cover different phases of corporate development. This means that similarities or even the same characteristics exist across some groups. Group types I, II, and III are therefore also expressions of a time horizon of corporate group development, starting with type I to the present type III. Table 3 in the next section then divides the main home-established corporate groups into the following three categories: (1) industrial groups (also called type I groups); (2) pyramid-like groups (type II groups); and (3) financial groups (type III groups or FIGs). If taken chronologically,

\footnotetext{
${ }^{1}$ However, there are some important studies, which appeared in early 1990s (Stark, 1996, on recombinant property and group structures).
} 
however, one would have to make some other structuring or typology, because today one can find both type I and III groups together (with some rather relics of type II groups as well) on the markets.

It is possible find some type I groups existing today, but often in a completely different form (often not so fragmented as in the earlier phase of transformation) and with different owners (often foreign ones). A good example of this is former VSZ Kosice. Originally privatized by means of a sort of management buyout, the firm was later taken-over by US Steel (Olsson, 1999).

Table 1

Typology of FIGs

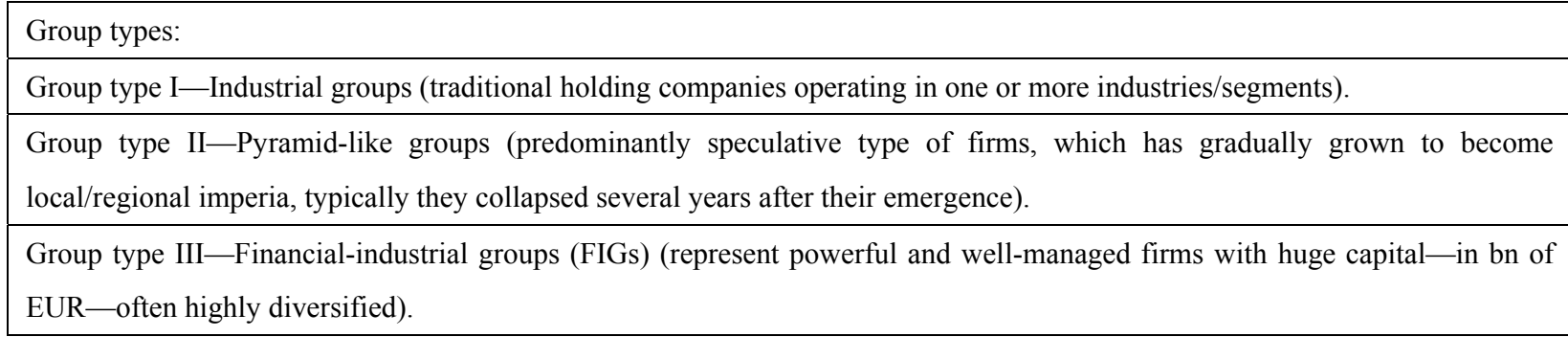

Note. Source: The author's own.

Our paper shows that financial groups (type III groups) are now becoming a powerful force in the corporate sector in both countries and create different ownership/industrial structures. Furthermore, they have not (yet) been affected by large (especially foreign) investors. The Správa prvního privatizačního fondu (that became the PPF Group) is seen here as the main representative of the type III groups. In 1991, PPF had already established an office aimed at the administration of a prepared investment fund. Later, Prvni privatizacni fond, a privatization fund representing the core of the PPF, was established, and by 1994, PPF had collected approximately five billion CZK in assets. Having laid out the general characteristics of type III firms, the case study charts the development of PPF as a way of illustrating these characteristics. It shows how this type of corporate group has become important.

Existing diseconomies caused by the excess size of a group can, however, be offset by other effects. Under relatively weaker corporate governance systems and poorer property rights protection in transitional economies, it may be profitable to organize information and resource transfers through a larger corporate group, despite any possible diseconomies. Indeed, one of the most important explanations for the development of high levels of ownership concentration in Eastern Europe (of which corporate groups are one expression) is that concentrations of ownership and complex control vehicles are response to inadequate protection of investors (La Porta et al., 1997).

Table 1 shows the range of analytical factors that provide a context for the development of ownership concentration and corporate groups. The table serves to help explain the development of type III corporate groups, but can be used to help explain the development of all three types of corporate groups. It shows that the factors affecting group development can be understood in terms of two broad dimensions: the institutional and the corporate framework. Further, within the institutional framework, both the environment confronting shareholders and users of capital markets will affect the way that corporate groups develop. Moreover, within the corporate framework, the independence and efficiency of corporate regulatory system, as well as the transparency and responsibility of the corporate governance system will affect corporate group development. Finally, strategic and competitive power factors within the corporate framework will affect the development of corporate groups. 
In explaining the development of type III groups, this paper suggests that strategic factors (scope of activities covered-SCOAC-C and high profit activity share on total activities HIAC-C) and competitive power (POW-C) issues, together with ownership related issues (OW-I and INV-I) have been particularly important. C and I, respectively, in abbreviations means corporate or institutional framework element. Given their importance for the analysis of the ownership structure within type III groups and corporate governance issues, the paper also mentions rate of equality among shareholders (SHE-C). The paper suggests that for further growth of the type III groups, a more balanced dealing with different stakeholders (and especially particular shareholder groups) will now become more critical. After all, it is widely accepted that it has been this factor, which has been a source of many problems in corporate development in most transition economies. This structural weakness and the absence of properly specified legal protections have substantially marked the development of capital markets in the Czech Republic and Slovakia. These weaknesses have had, however, an uneven impact. It provided advantages for the some groups of shareholders, especially to large (majority-insider) shareholders.

Table 2 provides some specification of the analytical context applied to the two basic corporate governance models-Anglo-Saxon and continental. The structure of corporate governance has certainly exerted a substantial influence over the process of ownership concentration and the emergence of all three types of groups. Irrespective of the specific type of privatization employed, certain forms of legal arrangements along with a traditional aversion to meet ethical standards vis-à-vis the state and business partners, there would not have been probably such processes of ownership concentration, which we have seen since 1990s. On the other hand, the historical fact is that everywhere around the globe a concentration of property in reform period had been aggressive and massive in both scale and scope.

Table 2

Specification of the Analytical Context: Two Basic Models

\begin{tabular}{|l|l|l|l|l|l|l|l|l|}
\hline Model & $\begin{array}{l}\text { OW-I } \\
\text { ownership }\end{array}$ & $\begin{array}{l}\text { INV-I } \\
\text { investment }\end{array}$ & $\begin{array}{l}\text { STDEV-I } \\
\text { stock market } \\
\text { development }\end{array}$ & $\begin{array}{l}\text { TAK-I rate of } \\
\text { takeover } \\
\text { activity }\end{array}$ & BO-C Board & $\begin{array}{l}\text { INC-C } \\
\text { Incentives }\end{array}$ & $\begin{array}{l}\text { DIS-C } \\
\text { Disclosure }\end{array}$ & $\begin{array}{l}\text { SHE-C } \\
\text { shareholder } \\
\text { protection }\end{array}$ \\
\hline A & Dispersed & $\begin{array}{l}\text { institutional } \\
\text { investors }\end{array}$ & High & High & $\begin{array}{l}\text { Majority of } \\
\text { non-executive } \\
\text { members }\end{array}$ & $\begin{array}{l}\text { Widely-set } \\
\text { stimuli }\end{array}$ & High & High \\
\hline B & Concentrated & $\begin{array}{l}\text { families, } \\
\text { banks, } \\
\text { public sector }\end{array}$ & $\begin{array}{l}\text { low (especially } \\
\text { for the new } \\
\text { issues) }\end{array}$ & $\begin{array}{l}\text { Limited } \\
\text { composed } \\
\text { from insiders }\end{array}$ & $\begin{array}{l}\text { Stimuli } \\
\text { related to } \\
\text { main } \\
\text { shareholders }\end{array}$ & Limited & $\begin{array}{l}\text { Weak } \\
\text { protection } \\
\text { of minority } \\
\text { shareholders }\end{array}$ \\
\hline
\end{tabular}

Notes. Model A = Anglo-Saxon model; Model B = continental model; Source: The author's own.

Table 4 does not cover all industrial groups existing in the Czech and Slovak republics. Several other large actors operate in coal mining (Kolacek group, Czech Coal), agriculture and food processing (Agropol Group), petrol, travel, and tourism (Unimex group) and real estate. Other groups are established or controlled by foreign companies, e.g., Siemens group in Slovakia or ABB in the Czech Republic.

\section{Emergence and Developmental Strategies of FIGs}

Given the fact that voucher privatization was designed and for the first time used on a wide-scale basis in the Czech Republic, it was natural that this model had been used also in some other countries, which had copied this model with some modifications later on (e.g., in Bulgaria or Russia). Several authors have written on the topic of 
voucher privatization specifically (Claessens, Djankov, \& Pohl, 1996) or on privatization in the Czech Republic in general (Coffee, 1996). Studies of ownership concentration in Western Europe and CEECs (Olsson \& Brzica, 2001; Olsson \& Alasheyeva, 2000) confirm that for various reason the concentration of listed companies was quite high in late 1990s.

Development of corporate groups is the result of ongoing ownership concentration in the Czech and Slovak economies and can be characterized by several periods. Several types of financial and industrial groups have appeared since 1990s, but now it is evident that only some of them have survived and even smaller part of them have become FIGs. In this chapter, five subchapters cover main aspects of FIGs' emergence and developmental strategies

\section{Type III Groups: Concentration, Conflict, and Cooperation}

The type III groups compete intensively within the Czech and Slovak republics. For them, the transfer of remaining state stakes in companies or bad debts claims has been a central way they have been able to expand at such a rapid pace. Table 3 provides a more detailed picture of the corporate groups in the two countries selected.

Table 3

Typology With Some Representatives for Each Type Group (Examples)

\begin{tabular}{|c|c|c|}
\hline \multicolumn{3}{|c|}{ Group Types: } \\
\hline \multicolumn{3}{|c|}{ Type I-Industrial groups } \\
\hline$\bullet$ & Chemapol group & (Czech Republic) \\
\hline • & Skoda Plzen group & (Czech Republic) \\
\hline • & VSZ Kosice group & (Slovakia) \\
\hline • & HTC holding & (Slovakia) \\
\hline • & IPB Group (financial group with stakes in industrial firms) & (Czech Republic) \\
\hline • & Skoda Plzen Group & (Czech Republic) \\
\hline • & Majsky group & (Slovakia) \\
\hline • & Agrofert Holding & (Czech Republic) \\
\hline
\end{tabular}

Type II-Pyramid-like groups

- $\quad$ BMG Invest CR

(Czech Republic)

- $\quad$ BMG Invest

(Slovakia)

- Horizont Slovakia

(Slovakia)

- Drukos

(Slovakia)

- $\quad \mathrm{AGW}$

(Slovakia)

Type III-Financial-industrial super groups (FISGs)

- $\quad$ PPF Group

(Czech Republic)

- $\quad$ K\&K Capital Group (Komarek Group)

(Czech Republic)

- $\quad \mathrm{J} \& \mathrm{~T}$

(Czech Republic \& Slovakia)

- $\quad$ Penta Group

(Slovakia)

- Istrokapital

(Slovakia)

- $\quad \mathrm{CPI}$

(Czech Republic)

Note. For the cases of Chemapol group, VSZ group, and Skoda Plzen group see Brzica (2001). Source: The author's own. 
Whereas some groups have remained concentrated purely on their home market, others have expanded to the East (PPF), to the West (HTC) or in both directions (Komarek group - to the former Soviet territory and Norway). There are three possible reasons for doing this: (1) to compete later on the EU market; (2) to counter balance local or national competitors; and (3) to expand eastward later on. Table 4 presents a basic description of the type III groups' representatives.

\section{Table 4}

Type III Actors-Basic Description

(1) Penta Group - Penta is one of the most important financial groups. It operates in both Slovakia and the Czech Republic.

(2) HTC Holding-It is the Slovak financial group controlling the Czech biggest tractor producer Zetor Brno. HTC consists of 13 companies. As of December 31, 2002, it reported sales of 19.8 bn SKK and employed 8,000 people. Zetor reported in 2002 profit 3.436 bn CZK compared with 2001's loss of $631 \mathrm{mn}$ CZK.

(3) Istrokapital-Istrokapital has been created by merger of four investment funds from the first wave of voucher privatization. Originally the funds had been under management of Slovenska sporitelna, a.s., Bratislava (Slovak insurance company), which sold its shares.

(4) PPF group - PPF is a private international financial group based in the Netherlands. Founded in 1991, currently this group focuses on consumer finance, insurance, banking, and real estate business. It operates in the Czech Republic, Slovakia, Belarus, China, Cyprus, Kazakhstan, Russia, Ukraine, and Vietnam. The group consisted of specialized companies (10); financial institutions (15); and a media company (1) in late 1990s. It is majority-owned by Petr Kellner (who controls 94\%) PPF belongs to the most important financial groups in the Czech Republic. It controls property in volume of 359 bn CZK and controls 317 companies (2011 data).

(5) K\&K Capital group (K. Komarek group) - The group is active in petrol business and industrial production. Komarek Group also acquired Atlantik financni trhy (AFT) in late 1990s making thus the group also rooted in financial operations. Later on, AFT was sold in 2010 to J\&T. KKCG recently divided into two separate holdings. The group controlled 42 bn CZK assets in 2007.

(6) Agrofert Holding-Agrofert Holding represents a holding in agricultural business. Agrofert is a type I group survivor so far without any financial branch. This case shows that some of the former type I groups persist on the scene.

(7) Czech Coal - the group controlled by P. Tykac is one of the biggest owners of Czech coalmines.

(8) J\&T-important group focused on energy, banking and finance, real estate, media.

(9) Karbon Invest - controlled by Z. Bakala. Bakala originally focused on finance recently concentrates on coal business. Currently Bakala owns NWR (New World Resources) company (coal business) and via his investment company RPG he owns, e.g., 44 thousand flats.

(10) EC Group - controlled by J. Dienstl. Received state claims from Czech consolidation agency in volume of 39 bn CZK in 2003.

Note. Source: The author's own.

So far, only limited data are available for the analysis of these groups, and this gives researchers only a limited set of options. Hence, we have chosen to use anecdotal evidence in combination with the presentation of selected sample of the main players. In one older survey of investment companies and investment funds (Brzica, 
1996), several of the biggest fund managers expressed then their willingness to become active administrators of firms in their portfolio. Legal barriers, however, have changed their possibilities for a while but some of their dreams have continued throughout the whole 1990s.

What has been typical for all main FIGs since their emergence in 1990s is their bi-polar nature of their business. As most of FIGs are large groups within their home countries they, as a result, both compete and cooperate among themselves. The reason is simple, in public tenders many of them are interested to participate and hence they compete there or, alternatively, they form consortia in which they cooperate (see Table 5 for illustration).

Table 5

Competition Over Stakes-Some Examples

\begin{tabular}{|l|l|l|l|}
\hline Firm & Industry & Value & Bidders/competitors \\
\hline Unipetrol $^{2}$ & petrol & 15 bn CZK & $\mathrm{B}$, other firms $^{*}$ \\
\hline Severoceske doly & coalmining & millions of CZK & $\mathrm{J}, \mathrm{P}$, other firms $^{*}$ \\
\hline TV NOVA & TV broadcasting & billions of CZK & $\mathrm{PP}$ \\
\hline State claims & various industries & billions of CZK & $\mathrm{PP}^{* *}, \mathrm{~J}^{* *}, \mathrm{P}, \mathrm{EC}$, other firms $^{*}$ \\
\hline Fischer group & travel agencies & millions of CZK & $\mathrm{P}, \mathrm{K}, \mathrm{J}$ \\
\hline Cesky Telecom & telecommunications & 50 bn CZK & $\mathrm{PP}$ \\
\hline Sazka & lottery & billions of CZK & $\mathrm{J}, \mathrm{P}, \mathrm{CPI}$, other firms \\
\hline
\end{tabular}

Notes. $\mathrm{PP}=\mathrm{PPF} ; \mathrm{B}=$ Babis group (Agrofert); $\mathrm{P}=$ Penta group; $\mathrm{J}=\mathrm{J} \& \mathrm{~T}$ group I = Istrocapital; $\mathrm{K}=$ Komarek group; $\mathrm{EC}=\mathrm{EC}$ group;

${ }^{*}$ There are also some other competitors but they do not represent the groups studied here; ${ }^{* *}$ Penta is together with J\&T Finance one of the biggest Slovak type III groups, which business focus is especially on trades with bad debts. Source: The author's own.

\section{Ownership and Control Dynamics of Type III Groups}

What makes the difference between the three categories of groups mentioned earlier important for the changing corporate landscape (and therefore for researchers) are differences in the dynamics and strategic focus as well as the composition of their activities between the different types of group structures. Whereas the type I and II groups could be characterized as having quite stable strategic focus, especially on acquiring stakes in industrial companies (in the case of the type I groups) or collecting money from investors (in the case of the type II groups), the type III groups are more dynamic in pursuing their strategic goals. Demsetz and Lehn (1985) postulate that owner control should be more valuable in firms where rapid, uncertain changes in the operating environment make it difficult to evaluate the effort of management. This is indeed the characteristic feature of the present business environment in certain segments of the Czech and Slovak industries where further important privatizations are to be expected.

Having the PPF group in the sample of type III groups, it is easy to show that the dynamics inherent to the

\footnotetext{
${ }^{2}$ Participation in the privatization of Unipetrol announced then the Hungarian petrol and gas company MOL; the Polish PKN Orlen (in consortium with Agrofert); the Russian company Yukos and TNK-BP; ConocoPhilips and Agip. Both Agip and ConocoPhillips had already stakes in Unipetrol and planned to increase their stakes in the company.

3 The consortium Tel Source, representing KPN (The Netherlands) and Swisscom (Switzerland), had decided to sell 27 percent of Cesky Telekom shares. The PPF group, as financial investor, searched for new investment opportunities. Cesky Telekom had been evaluated from this perspective but given the circumstances the purchase of its shares was not considered attractive enough for the PPF.
} 
group has helped it to survive and avoid the destiny of other type I groups. ${ }^{4}$ Internal efficiency of the type III groups is probably higher than that for the type I and definitely higher than for the type II, because responsiveness to change is integral to their strategic and structural orientation. Initial ownership dynamics of the type III groups could have been hampered due to several factors. Among them especially important are: (1) an increasing competition from abroad in particular segments nowadays controlled by the groups; (2) a global pressure to concentrate on core technologies; and (3) problems with management and control of complex business structures in a less developed institutional environment.

Compared with type I and II groups, which had focused on mainly industrial capital and real estate (type I) or money capital (type II), the type III groups are open to every opportunity to make profit. For this reason, they have created efficient structures to identify profitable opportunities, provide legal advice on all operations to avoid possible misconducts and potential suits, and to mobilize financial resources within the group to take advantage of the identified opportunities. They also organize restructuring, managing/maintaining, consulting or selling newly acquired assets. This is being made on such a wide-scale level that it can be considered as a completely new phenomenon despite some exceptions that existed within types I and II groups.

With the concentration process having intensified across many sectors of the Czech and Slovak economies, large parts of the economy are now controlled either by private groups/companies (or remain in state ownership). The "winner takes all" principle of current privatization and corporate takeover activity is forcing all the main players to be active in fights for receiving controlling stakes in different important companies be they in telecommunications (Telecom), petrol (Unipetrol), banking (Postovni banka) and others. Table 5 provides some examples of which groups have been competing over which stakes. From the privatization of Unipetrol, the Czech Republic expected to receive revenues up to $15 \mathrm{bn}$ CZK. As seen from the announced planned sales, a bid for these stakes required/s substantial capital available. Several groups from our sample confirmed that they have enough capital sources to be ready to use for such purposes.

We have observed so far that the Czech and Slovak corporate sector concentration for publicly listed companies is substantial. The group-related process of ownership concentration is permanent throughout the transition period in both countries as the groups analyzed collect still higher stakes in some important companies as shown by the cases of PPF or Penta group. In addition, there are several indicators suggesting that this process will continue. The forms and modes of concentration used by FIGs have been changing over time. It is evident that some practices and strategies: (1) do not work efficiently; (2) are no longer available (e.g., cheap bank credits); or (3) are no longer possible (due to higher competition on the market, new legislation etc.). The groups as intermediaries can, in some cases, "maintain" originally highly concentrated ownership structure of some former state companies unchanged, because, through bids, they have access to bulk of shares in these companies. The Cesky Telecom case is one such example of this phenomenon. The dynamics of different types of groups have widened substantially in terms of durability (persistence), complexity and scope or profitability. Nowadays they also more efficiently use an opportunity to be incorporated abroad. ${ }^{5}$

As regards ownership structure, in many cases FIGs are either family-owned (KKCG, EC group),

\footnotetext{
${ }^{4}$ Sometime the IPB case is mentioned in this regard because of some similarities between IPB and PPF structures.

5 Being dynamic and powerful also means that a group should pay substantial amount of taxes. Therefore, the mother company of the whole group, Penta Holding Ltd., is for the tax purposes registered in Cyprus.
} 
individually owned (PPF), or owned by small number of individual majority owners (Penta group, J\&T).

\section{Restructuring Dynamics of Type III Groups}

The emergence of type III groups, together with a new state policy of selling claims of Czech consolidation agency (a state agency responsible for dealing with claims of state), have generated higher dynamics to the whole process of restructuring. Not successful initial bank and type I group-lead restructuring have been gradually substituted by more successful type III groups-lead restructuring. Whereas both the Czech and Slovak banks had not been successful in solving the situation with their bad debts and claims, the type III groups had been very dynamic and successful here. Usual time-period of solving such a case was less than one year, ${ }^{6}$ any operation lasting more than one year was considered as a failure and such claims were written-off.

Despite the literature on the relation between corporate concentration and restructuring is not well developed in transition economies, the results from developed countries have shown substantial interrelatedness between the two aspects. Hence, one has a good reason to believe that making the industrial structure more concentrated can lead in turn to further restructuring. Restructuring activities are considered here in a wider sense. They include not only corporate/industrial restructuring processes but also innovations generated by the type III groups leading to changes in institutional environment and organization setting on the national level. So far, there have been several such changes made also by the type I and II groups. In the case of type III groups, one change affected completely corporate sector. It was the initiative of the two companies cooperating on the Czech and Slovak markets (J\&T Global, a member of J\&T group and MEI-Middle Europe Investment from the Netherlands) to trade IPOs of shares related to business in real estates in the Czech Republic and Slovakia. The two firms have created Middle Europe Real Estate (MERE), a close-end fund with assets value of $100 \mathrm{mn}$ EUR, where J\&T Global and MEI have become joint fund administrators.

In general, restructuring of an economy in transition requires a committed government providing consistent and widely supported economic policy as well as some business actors capable to initiate needed changes. Strategic investors from the voucher privatization-some strategically oriented investment companies and investment funds ${ }^{7}$; industrial groups of the type I and some individually owned "family imperia" — could not have obtained enough power to contribute to substantial concentration of ownership in medium-term horizon. Many of them have either been transferred into portfolio players, have collapsed or been marginalized by (often foreign) competitors. In the latter two groups (collapsed and marginalized firms) one can find Chemapol group or Skoda Plzen, both type I Czech groups. One type I group from Slovakia, VSZ Kosice, has followed still another development path. Being not a fund but an industrial firm, it has not collapsed or been marginalized but has returned to its core business with its previously strong capacity. However, it is no surprise also here that Penta had been interested in control over this company.

Unlike the groups from previous periods, nowadays the biggest groups have quite different operating possibilities. Whereas at the beginning of transformation the type I and II groups had to deal with both the state

\footnotetext{
${ }^{6}$ Usual schedule for the operation was that in one month these groups or specialized agencies contacted debtors, in less than three months made an agreement or find buyers and then received payments.

${ }^{7}$ Since 1996 several investment companies have transformed themselves into holding companies to avoid anti-strategic fund regulation.

${ }^{8}$ Charouz group, once a single man-owned company, had in mid 1990s about 1,000 firms in its portfolio.
} 
and broad public, now the main partner for the groups in some activities is the state only and in other deals other powerful groups. Such a situation was possible to see in the case of acquiring claims from the Czech consolidation agency in volume of billions of CZK or in privatization of important state stakes in strategic companies, like, e.g., in Czech Telecom or Czech post. In times of voucher privatization there had been disputes with the government but most activities concentrated on attracting enough individual voucher investors to invest in particular funds (or to have sufficient number of investors to deposit money in the case of the type II groups). Although their investment opportunities are limited, their knowledge of how to use existing institutional environment (especially laws and tender procedures) are deep. Hence, the type III groups are unusually successful in public tenders organized by the state and usually it is the groups, which appear on short-lists for such tenders. In some cases, they initiate legal suits to satisfy their claims or to protect their rights. Nevertheless, FIGs are also successful in usual business. PPF Group, the biggest investment group in Central and Eastern Europe, received (in 2010) a permission of the Chinese regulator in banking CBRC to found a non-banking company for providing consumer credits in one Chinese city. This approval gives PPF group the right to establish - in line with the law on consumer credits adopted in China in 2009- the first company for consumer credit operations, which will be fully owned by foreign investor. In total in four Chinese cities is to be allowed to establish firms for consumer credits and these cities/firms should be a pilot for development of this financial industry in the whole China. Among the recent activities of FIGs belong huge investments into real estates, but this activity has been reduced since the beginning of the global financial crisis.

Currently, most of the groups mentioned in this paper dynamically develop its activities despite the ongoing crisis. The largest Italian insurance company Generali has agreed to acquire 49\% shares of Generali PPF Holding (GPH), a joint venture with Kellner's PPF. Generali, among other things, dominate the Ceska pojistovna (Czech Insurance Company), which is part of the GPH. For the PPF's share in GPH Italians pay 2.5 bn euros (about 63.8 bn CZK) (CTK, 2013).

\section{Some Policy Lessons From Transformation Process Related to FIGs}

Recent development of FIGs shows that such groups can serve a positive role in post-transformation economies. It thus confirms the hypothesis that in a transitive economy market uncertainty and instability motivate firms and other business actors to behave in such a way as to stabilize internally market conditions by formation of diversified conglomerates. Our analysis indicates that FIGs are very often focused on high profit margin activities based on deals both with private firms/FIGs and state organizations/institutions. Their economic power and ability to find and invest in attractive projects make them less vulnerable to crisis - as was shown, e.g., by PPF. From a policy perspective is highly discussed the issue of (relative) closeness of these groups. If not directly person-owned or family-owned then often such groups have a small number of high-stake owners.

An analysis of the groups is important for transitional economies for two reasons: (1) it provides an explanation of the concentration processes within the economies; and (2) it helps to understand why some particular modes of privatization and concentration take place and what kind of industrial structure can be expected to arise in the next future.

To summarize some key elements relevant for other countries one can mention the following ones:

- Regulators must stimulate competition and avoid "imperfections" in legislation, which can lead to erosion of 
competition. Nevertheless, as identified by north, due to active participation of business interest groups in legislation process (directly or indirectly through lobby groups/persons) such task is very difficult and sometimes impossible;

- Timing and sequencing of steps in reform process can have certain impact on FISGs emergence. However, initial conditions matter probably more due to the inherent industrial structure of a country than do reforms specificities;

- As the Czech and Slovak cases demonstrate, despite several mistakes of policymakers at the beginning and during the transition process the resulting post-reform situation is in both countries quite good. Both countries' competitiveness remains well above those of many other post-reform countries and even global financial crisis has had a comparatively modest impact on economic development;

- Together with foreign direct investments, FIGs has become since their emergence an important vehicle for exporting investment activities - one most visible example is the one of PPF, which has become the only fully foreign-owned company receiving a license to provide consumer credit services to population in China. It is important to note that for PPF this kind of business represent one of the core businesses, which is highly profitable.

\section{Conclusions}

The partial results, which have been presented so far indicate that: (1) group-related process of ownership concentration is permanent throughout the transition period in both countries; (2) forms and modes of concentration used by groups have changed over time; and (3) such intermediaries can, in some cases, "maintain" originally highly concentrated ownership structures of some former state companies unchanged. The dynamics of different types of groups have widened substantially in terms of durability (persistence), complexity and scope or profitability. Legal and ethical positions of their operation are also very important from an economic policy standpoint but for our purposes have been left aside here and therefore were not discussed.

We have shown that the dynamics and structure of different types of groups are important features explaining, at least partly, why some groups have become more powerful over time while other have either been rendered unstable or collapsed entirely.

\section{References}

Brzica, D. (1996). The role of investment companies and investment fund managers in exercising ownership rights. Russian and East European Finance and Trade, 32(4), 47-66.

Claessens, S., Djankov, S., \& Pohl, G. (1996). Ownership and corporate governance: Evidence from the Czech Republic. Retrieved $\begin{array}{llll}\text { November } & 8-9, & 1996, & \text { from }\end{array}$ http://www-wds.worldbank.org/external/default/WDSContentServer/IW3P/IB/2000/02/24/000009265_3971110141228/addit ional/117517322_20041117180553.pdf

Coffee, J. C. (1996). Institutional investors in transitional economies: Lessons from the Czech experience. In R. Frydman, Ch. W. Gray, \& A. Rapaczynski (Eds.), Corporate governance in central Europe and Russia (pp. 111-186). Budapest: CEU Press.

CTK. (2013). Generali ovládne českou pojištovnu, odkoupi podíl Kellnerovy PPF. Retrieved from http://www.financninoviny.cz/zpravy/generali-ovladne-ceskou-pojistovnu-odkoupi-podil-kellnerovy-ppf/886027

Demsetz, H. (1983). The structure of ownership and the theory of the firm. Journal of Law and Economics, 26(2), 375-390.

Demsetz, H., \& Lehn, K. (1985). The structure of corporate ownership: Causes and consequences. Journal of Political Economy, 93 , $1155-1177$. 
Ellerman, D. (1998). Voucher privatization with investment funds. The William Davidson Institute Working Paper, No. 167, University of Michigan Business School.

La Porta, R., Lopez de Silanes, F., Shleifer, A., \& Vishny, R. W. (1997). Legal determinants of external finance. Journal of Finance, 52, 1131-1150.

March, J. G., \& Simon, H. A. (1958). Organizations. New York: Willey.

Mertlik, P. (1997). Czech privatization: From public ownership to public ownership in five years? Eastern European Economics, 35, 64-83.

Olsson, M. (1999). Ownership reform and corporate governance: The Slovak Privatisation Process in 1990-1996 (Acta Universitatis Upsaliensis, Uppsala Studies in Economic History No. 49).

Olsson, M., \& Alasheyeva, J. (2000). Market transparency, ownership concentration and harmonization of law in some east European countries: A critical note. Paper presented at the conference of Economic Aspects of European Integration. Sweden: Mölle.

Olsson, M., \& Brzica, D. (2001). Corporate governance in transitional economies: The case of the Czech Republic. Paper presented at the ACE workshop on Corporate Governance and the Accession Countries, Portoroz, Slovenia.

Pistor, K., \& Spicer, A. (1997). Investment funds in mass privatization and beyond: Evidence from the Czech Republic and Russia. Retrieved from http://www.cid.harvard.edu/hiid/565.pdf.

Simoneti, M., Estrin, S., \& Boehm, A. (1999). The governance of privatization funds: Experiences of the Czech Republic, Poland and Slovenia. London: Edward Elgar.

Stark, D. (1996). Recombinant property in East European capitalism. American Journal of Sociology, 101(4), 993-1027.

Tirole, J. (1991). Privatization in Eastern Europe: Incentives and the economics of transition (draft). Cambridge/Mass: Massachusetts Institute of Technology.

Williamson, O. E. (1975). Markets and hierarchies: Analysis and antitrust implications. New York: Free Press. 